\title{
Feeding ecology of the lizard Tropidurus oreadicus Rodrigues 1987 (Tropiduridae) at Serra dos Carajás, Pará state, northern Brazil
}

\author{
Rocha, CFD. and Siqueira, CC. * \\ Departamento de Ecologia, Universidade do Estado do Rio de Janeiro - UERJ, \\ Rua São Francisco Xavier, 524, Maracanã, CEP 20550-013, Rio de Janeiro, RJ, Brazil \\ *e-mail: carlacsiqueira@yahoo.com.br \\ Received May 31, 2006 - Accepted December 7, 2006 - Distributed February 29, 2008
}

\begin{abstract}
Tropidurus species commonly prey on arthropods, but they may also feed on vertebrates and plant material. The lizard Tropidurus oreadicus (Tropiduridae) is common in open vegetation habitats and generally has sexual dimorphism. In this study we analyzed the diet of T. oreadicus at Serra dos Carajás, Pará, in the north of Brazil. Snout-vent length (SVL) and jaw width (JW) were taken for 34 lizards. There was a significant difference in SVL and in JW, with males being larger than females. All lizards analyzed contained food in their stomachs. The diet of T. oreadicus at Serra dos Carajás was characterized by the consumption of a relative wide spectrum of food item categories (21 types of items), consisting of arthropods, part of one vertebrate and plant material, which characterizes the diet of a generalist predator. Volumetrically, the most important items in the diet of both sexes of T. oreadicus were flowers $(\mathrm{M}=61.7 \% ; \mathrm{F}=33 \%)$ and orthopterans $(\mathrm{M}=1.7 \% ; \mathrm{F}=3.5 \%)$. Ants were the most frequently consumed (100\% for both sexes) and the most numerous $(\mathrm{M}=94.5 \% ; \mathrm{F}=89.4 \%)$ food item. Flowers also were frequently consumed $(\mathrm{M}=91.7 \% ; \mathrm{F}=54.5 \%)$, with their relative consumption differing significantly between sexes. There was not a significant sexual difference in prey volume, neither in number of preys per stomach, nor in type of prey ingested. There was no relationship between lizard jaw width and the mean volume of prey. The data showed that T. oreadicus is a relatively generalist lizard in terms of diet and that consumes large volumes of plant material, especially flowers of one species of genus Cassia. Keywords: Tropiduridae, feeding ecology, Tropidurus oreadicus.
\end{abstract}

\section{Ecologia alimentar do lagarto Tropidurus oreadicus (Tropiduridae) na Serra dos Carajás, estado do Pará, norte do Brasil}

\begin{abstract}
Resumo
Espécies de Tropidurus comumente predam artrópodos, mas eles também podem consumir vertebrados e material vegetal. O lagarto Tropidurus oreadicus (Tropiduridae) é comum em habitats de vegetação aberta e geralmente possui dimorfismo sexual. Neste estudo, analisamos a dieta de T. oreadicus na Serra dos Carajás, Pará, Norte do Brazil. O comprimento rostrocloacal (CRC) e a largura da mandíbula (LM) foram medidos em 34 lagartos. Houve diferença significativa em termos do CRC e da LM, com os machos sendo maiores do que as fêmeas. Todos os lagartos continham alimento em seus estômagos. A dieta de $T$. oreadicus da Serra dos Carajás foi caracterizada pelo consumo de uma grande variedade de categorias de itens alimentares (21 tipos de itens), consistindo de artrópodes, de parte de um vertebrado e de material vegetal, o que caracteriza a dieta de um predador generalista. Volumetricamente, os itens mais importantes na dieta de ambos os sexos de T. oreadicus foram flores $(\mathrm{M}=61,7 \% ; \mathrm{F}=33 \%)$ e ortópteros $(\mathrm{M}=1,7 \% ; \mathrm{F}=3,5 \%)$. Formigas foram os itens mais freqüentemente consumidos (100\% para ambos os sexos) e os mais numerosos $(\mathrm{M}=94,5 \% ; \mathrm{F}=89,4 \%)$. Flores também foram freqüentemente consumidas $(\mathrm{M}=91,7 \% ; \mathrm{F}=54,5 \%)$, diferindo significativamente em consumo entre os sexos. Não houve diferenças sexuais em volume, em número, nem em tipos de presas ingeridas. Não houve relação entre largura da mandíbula dos lagartos e a média do volume de presas. Os dados mostraram que T. oreadicus é um lagarto relativamente generalista em termos de dieta e que consome grande volume de material vegetal, especialmente flores de uma espécie do gênero Cassia.
\end{abstract}

Palavras-chave: Tropiduridae, ecologia alimentar, Tropidurus oreadicus.

\section{Introduction}

The genus Tropidurus (Tropiduridae) (sensu Frost et al., 2001) consists of predominantly heliophilous lizard species (e.g. Rocha and Bergallo, 1990; Van Sluys, 1992; Kiefer et al., 2005), which are usually quite abundant locally, occurring in open habitats in South

America (Rodrigues, 1987; 1988; Frost et al., 2001). Data on the diet of Tropidurus species that have been studied indicate that species of this genus tend to be generalized predators, consuming mainly arthropods, and use the "sit and wait" strategy to catch their animal 
preys (e.g. Bergallo and Rocha, 1993; Faria and Araújo, 2004). They also can occasionally prey on vertebrates (e.g. Alvarez et al., 1985; Vitt et al., 1996; Cruz et al., 1998; Faria and Araújo, 2004; Kokubum and Lemos, 2004; Kiefer et al., 2006), including conspecifics (e.g. Alvarez et al., 1985; Araújo, 1987; Kiefer and Sazima, 2002; Dias and Rocha, 2004), and eat a variable amount of plant material (e. g. Alvarez et al., 1985; Araújo, 1987; Colli et al., 1992; Van Sluys, 1993; Vitt, 1993; Rocha and Bergallo, 1994; Vitt et al., 1996; Cruz, 1998; Cruz et al., 1998; Fialho et al., 2000; Rocha et al., 2002; Faria and Araújo, 2004).

Tropidurus oreadicus Rodrigues 1987, the subject of this study, is a sexually dimorphic species with males being larger than females (Araújo, 1987; Rodrigues, 1987; Vitt, 1993). It is a lizard usually abundant in open vegetation habitats (Colli et al., 1992), common in Central Brazilian "Cerrado" areas and also occurring in open enclaves in the Amazonian forest, south of the Amazon River (Rodrigues, 1987). At the Serra dos Carajás ("Canga" habitat), northern Brazil, this lizard usually occurs in high densities and has an extensive diurnal activity period from early morning to late afternoon, with a decrease near midday (Rocha and Bergallo, 1990). In this habitat, T. oreadicus is found active on the ground and, most frequently, on iron ore rocks, living in sympatry with other lizard species such as Ameiva ameiva Linnaeus, 1758, Tupinambis teguixin (Linnaeus, 1758), Cnemidophorus lemniscatus (Linnaeus, 1758), Kentropyx calcarata Spix, 1825 (Teiidae), Mabuya nigropunctata (Spix, 1825) (Scincidae), Uranoscodon superciliosus (Linnaeus, 1758) (Tropiduridae), Anolis nitens chrysolepis Duméril and Bibron, 1837 (Polychrotidae) and Iguana iguana (Linnaeus, 1758) (Iguanidae) (Araújo, 1987; Vitt, 1993).

Tropidurus oreadicus, in the Cerrado habitats of Mato Grosso and Goiás States ("Cerrado" biome), primarily consume arthropods and some plant material (Colli et al., 1992; Faria and Araújo, 2004). Information regarding the diet of this species in Serra dos Carajás can be found in Araújo (1987) and Vitt (1993) however, since neither of the studies provides data on the frequency of each prey category, and furthermore in Araújo's study (1987) the volume of individual plant categories consumed (flowers, seeds, fruits) is not presented, a more comprehensive knowledge of the diet of this species is necessary.

In this study we analyzed the diet of Tropidurus oreadicus at Serra dos Carajás, Pará State, in the north of Brazil, assessing the occurrence of sexual variation in feeding habits, especially in relation to the consumption of plant material, and comparing the diet composition to that of some other conspecific and congeneric sympatry populations in other areas.

\section{Material and Methods}

Lizards were collected by the first author in a “Canga" habitat in July 1988, near Serra Norte (5²5' S and $\left.49^{\circ} 53^{\prime} \mathrm{W}\right)$, at the Serra dos Carajás, Pará State, northern Brazil. The "Canga" consists of outcropping concretions of iron ore, typically $3 \mathrm{~m}$ or more thick, producing irregular stony fields colonized predominantly by herbaceous (open canga) and shrubby (dense canga) vegetation (Secco and Mesquita, 1983). At Carajás, canga fields occur as plateaus on hilltops surrounded by Amazonian liana forest.

We collected lizards, using a noose or a rifle, while they were active (between 07:00 AM and 06:30 PM) in areas of exposed rocks. After collection, we fixed the animals with $10 \%$ formalin solution and later they were stored in $70 \%$ alcohol. Posteriorly, lizards were measured in their snout-vent length (SVL) and jaw width with a caliper (to the nearest $0.1 \mathrm{~mm}$ ).

Specimens were dissected and their stomach contents analyzed qualitatively and quantitatively in terms of number, volume and frequency. Animal preys were counted and identified to the level of Order (to Family, for ants). Unidentified arthropod remains were grouped in a separate category ("miscellaneous") and were considered only for volumetric analyses. Insect larvae were pooled in a category "All larvae". Plant items were categorized as flowers, fruits, leaves, seeds and unidentified parts ("plant remains"). Each food item found was measured for its length and width with a caliper (to the nearest $0.1 \mathrm{~mm})$ and its respective volume $\left(\mathrm{mm}^{3}\right)$ was calculated using the formula of an ovoid spheroid: $V=4 / 3 \pi$ (length/2) $(\text { width/2) })^{2}$ Dunham, 1983). The frequency of each prey in the diet was calculated from the proportion of lizards in the sample that had ingested that particular prey.

Body size (snout-vent length) differences between males and females of $T$. oreadicus were tested using oneway analysis of variance (ANOVA). To test for jaw width differences (independent of body size) between sexes we used an analysis of covariance (ANCOVA), with SVL as covariate. In order to analyze the effect of body size on prey size, we tested the relationship between the jaw width of lizards and the mean volume of the three largest preys using Simple Regression Analysis (Zar, 1999). To evaluate if there was significant variation in the number and volume of preys consumed between males and females, we realized one-way analyses of variance utilizing the mean of the three largest volumes of prey per stomach. Differences among sexes in the proportion of consumption of plant material, especially flowers ingested were tested using a Z test for proportions (Zar, 1999). Descriptive statistics are presented throughout the text as arithmetic mean \pm one standard deviation.

\section{Results}

Males of Tropidurus oreadicus from Serra dos Carajás averaged $69.9 \pm 13.5 \mathrm{~mm}$ in SVL (range 43.4-88.4 mm; $\mathrm{N}=12$ ) and $14.2 \pm 2.7 \mathrm{~mm}$ in jaw width (range 9.6-18.0 mm) and females averaged $60.9 \pm 13.7 \mathrm{~mm}$ in SVL (range 42.6-75.3 mm; $\mathrm{N}=22$ ) and $11.8 \pm 1.6 \mathrm{~mm}$ in jaw width (range 9.0-16.0 $\mathrm{mm}$ ). 
The two groups differed significantly in SVL (ANOVA, $\mathrm{F}_{1,33}=5.862 ; \mathrm{P}<0.05$ ) and in jaw width (ANCOVA, $\left.\mathrm{F}_{1,1,32}=4.707 ; \mathrm{P}<0.05\right)$.

All 34 lizards analyzed contained food in their stomachs. The diet of T. oreadicus in Serra dos Carajás consisted of arthropods (mainly insects), but also included plant material such as fruits, seeds, leaves and flowers (Table 1). The stomach of one female contained one foot of a conspecific. In terms of volume, the most important items in the diet of both sexes of $T$. oreadicus were flowers $(\mathrm{M}=61.7 \% ; \mathrm{F}=33.0 \%)$ and orthopterans $(\mathrm{M}=1.7 \% ; \mathrm{F}=3.5 \%)$. Ants $(1.3 \%)$ and larvae $(3.4 \%)$ constituted the third most voluminous item in the diet, for males and females respectively (Table 1). The most frequently consumed food items ( $100 \%$ for both sexes) and also the most numerous ( $\mathrm{M}=94.5 \%$; $\mathrm{F}=89.4 \%)$ were ants. Flowers were also important in terms of frequency, especially for males $(\mathrm{M}=91.7 \% ; \mathrm{F}=54.5 \%)$. Larvae $(1.9 \%)$ and seeds $(2.6 \%)$ were the second most important items in terms of number, for males and females respectively (Table 1).

There was not a significant sexual difference in prey volume (ANOVA, $\mathrm{F}_{1,33}=0.570 ; \mathrm{P}=0.456$ ), neither in number of prey per stomach (ANOVA, $\mathrm{F}_{1,33}=0.006$; $\mathrm{P}=0.937$ ), nor in the types of prey ingested (KolmogorovSmirnov, D $=0.364, \mathrm{p}=0.08$ ). The volume (Regression Analysis, $\mathrm{R}=0.098 ; \mathrm{F}_{1,33}=0.313 ; \mathrm{p}=0.580$ ) of preys did not vary significantly with jaw width. There was no difference between sexes in the proportion of individuals ingesting plant material $(\mathrm{Z}=-1.5 ; \mathrm{P}=0.07)$. However, when considering only the consumption of flowers, males consumed this item more frequently than females $(\mathrm{Z}=-2.454 ; \mathrm{P}<0.05)$.

\section{Discussion}

There was significant sexual dimorphism in body size for Tropidurus oreadicus from Serra dos Carajás, with males being larger than females, as found in other

Table 1. Diet composition for males and females of Tropidurus oreadicus at Serra dos Carajás, Pará State, northern Brazil. Number $(\mathrm{N})$ and volume $\left(\mathrm{V}\right.$; in $\left.\mathrm{mm}^{3}\right)$ of each food item category and proportion of stomachs with a given food item $(\mathrm{F})$ are listed with their respective percentages (\%).

\begin{tabular}{|c|c|c|c|c|c|c|}
\hline \multirow[t]{2}{*}{ Food items } & \multicolumn{3}{|c|}{ Males $(n=12)$} & \multicolumn{3}{|c|}{ Females $(n=22)$} \\
\hline & $\mathbf{N}(\%)$ & $\mathrm{V}(\%)$ & F $(\%)$ & $\mathbf{N}(\%)$ & $\mathrm{V}(\%)$ & F (\%) \\
\hline \multicolumn{7}{|l|}{ ARACHNIDA } \\
\hline Araneae & $5(0.6)$ & $41.8(0.2)$ & $4(33.3)$ & $13(0.9)$ & $62.8(0.4)$ & $10(45.5)$ \\
\hline Pseudoscorpiones & - & - & - & $1(0.1)$ & $0.8(0.01)$ & $1(4.5)$ \\
\hline \multicolumn{7}{|l|}{ MIRIAPODA } \\
\hline Chilopoda & $3(0.4)$ & $5.6(0.003)$ & $2(16.7)$ & $7(0.5)$ & $206.8(1.4)$ & $4(18.2)$ \\
\hline \multicolumn{7}{|l|}{ HEXAPODA } \\
\hline Orthoptera & $5(0.6)$ & $359.8(1.7)$ & $4(33.3)$ & $15(1.1)$ & $503.4(3.5)$ & $10(45.5)$ \\
\hline Isoptera & - & - & - & $9(0.6)$ & $6.4(0.04)$ & $3(13.6)$ \\
\hline Mantodea & - & - & - & $1(0.1)$ & $54.0(0.3)$ & $1(4.16)$ \\
\hline Blattodea & $2(0.3)$ & $107.3(0.5)$ & $2(16.7)$ & $3(0.2)$ & $202.9(1.4)$ & $3(13.6)$ \\
\hline Hemiptera & $1(0.1)$ & $91.7(0.4)$ & $1(8.3)$ & $7(0.5)$ & $153.0(1.1)$ & $4(18.2)$ \\
\hline Homoptera & $1(0.1)$ & $2.9(0.01)$ & $1(8.3)$ & $5(0.4)$ & $41.6(0.3)$ & $4(18.2)$ \\
\hline Coleoptera & $8(1.0)$ & $11.2(0.1)$ & $5(41.7)$ & $23(1.6)$ & $76.6(0.5)$ & $10(45.5)$ \\
\hline Neuroptera & $1(0.1)$ & $28.4(0.1)$ & $1(8.3)$ & - & - & - \\
\hline Formicidae & 740 (94.5) & $287.0(1.3)$ & $12(100)$ & $1273(89.4)$ & $279.0(1.9)$ & $22(100)$ \\
\hline Other Hymenoptera & $1(0.1)$ & $14.0(0.1)$ & $1(8.3)$ & $8(0.6)$ & $281.7(2.0)$ & $6(27.3)$ \\
\hline Lepidoptera & - & - & - & $5(0.4)$ & $108.5(0.8)$ & $3(13.6)$ \\
\hline Diptera & - & - & - & $1(0.1)$ & $1.3(0.01)$ & $1(4.5)$ \\
\hline All larvae & $15(1.9)$ & $66.7(0.3)$ & $5(41.7)$ & $11(0.8)$ & $491.9(3.4)$ & $7(31.8)$ \\
\hline Miscellaneous & - & $6759.2(31.0)$ & - & - & 5999.5 (41.8) & - \\
\hline Part of vertebrates & - & - & - & $1(0.1)$ & $175.5(1.2)$ & $1(4.5)$ \\
\hline \multicolumn{7}{|l|}{ PLANT FOOD } \\
\hline Fruits & $1(0.1)$ & $144.8(0.7)$ & $1(8.3)$ & $3(0.2)$ & $172.8(1.2)$ & 3 (13.6) \\
\hline Flowers & - & $13441.4(61.7)$ & $11(91.7)$ & - & $4734.4(33.0)$ & $12(54.5)$ \\
\hline Seeds & - & - & - & $37(2.6)$ & $120.9(0.8)$ & $8(36.4)$ \\
\hline Leaves & - & - & - & $1(0.1)$ & $5.0(0.03)$ & $1(4.5)$ \\
\hline Plant remains & - & $432.8(2.0)$ & - & - & $668.9(4.7)$ & - \\
\hline Total & 783 & 21794.7 & - & 1424 & 14347.4 & - \\
\hline
\end{tabular}


T. oreadicus populations (Araújo, 1987; Vitt, 1993; Faria and Araújo, 2004) and in other Tropidurus species (e.g. T. hispidus (Spix, 1825): Vitt, 1993; Vitt et al., 1996; T. itambere Rodrigues, 1987: Van Sluys, 1993; Faria and Araújo, 2004; T. spinulosus (Cope, 1862): Cruz, 1998; T. torquatus (Wied, 1820): Fialho et al., 2000; Pinto et al., 2005; T. semitaeniatus (Spix, 1825): Vitt, 1993).

All 34 lizards analyzed contained food in their stomachs, which indicates that the population must be in positive energy balance (see Huey et al., 2001). Sitand-wait lizards have a significantly lower incidence of empty stomachs than do widely foraging lizards in South America (Huey et al., 2001).

Our data showed that the diet of $T$. oreadicus at Serra dos Carajás was characterized by the consumption of a relative wide spectrum of food item categories (21 types of items), composed predominantly of invertebrates and plant material, which characterize the diet of a generalist predator. Males consumed fewer types of prey than females, but this difference could have been affected by the smaller sample size of males. A similar trend for the generalist diet has been found in other studies on $T$. oreadicus (Araújo, 1987; Colli et al., 1992; Vitt, 1993; Faria and Araújo, 2004). The consumption of a wide array of food item types, including both relatively sedentary (e.g. larvae) and highly mobile preys (e.g. ants and spiders), has also been found in other Tropidurus species (e.g. T. etheridgei Cei, 1982: Cruz et al., 1998; T. itambere: Van Sluys, 1993; Faria and Araújo, 2004; T. spinulosus: Colli et al., 1992; T. torquatus: Fialho et al., 2000).

Ants predominated in terms of number and frequency in both sexes. The high proportion of ants in the diet seems to be related to their high density in the area (Araújo, 1987) and to the high mobility of these insects, increasing their chance of contact with a sit-and-wait predator. Ants are usually very important items in the diet of Tropidurus species, a conservative character of their food niche ( $T$. etheridgei: Vitt, 1991; Cruz et al., 1998; T. hispidus: Vitt, 1993; Vitt et al., 1996; T. itambere: Van Sluys, 1993; T. montanus Rodrigues, 1987: Vitt, 1991; T. oreadicus: Colli et al., 1992; Vitt, 1993; Faria and Araújo, 2004; T. semitaeniatus: Vitt, 1993; T. spinulosus: Vitt, 1991; Colli et al., 1992; Cruz, 1998; T. torquatus: Rocha and Bergallo, 1994; Fialho et al., 2000; Juliano et al., 2002).

Both sexes consumed a considerable volume of plant material (64.4\% for males and $39.7 \%$ for females), which characterizes $T$. oreadicus as an omivorous species, since more than $10 \%$ of plant material was ingested (Cooper and Vitt, 2002). Ingestion of plants by lizards is often regarded as an accidental consequence of the capture of arthropod prey when foraging on vegetation. Considering that plant parts (mainly flowers, but also seeds, fruits and leaves) were found in $94.1 \%$ of all lizards examined and usually in considerable amounts, our data indicate that the ingestion was not accidental, and that plants are indeed a common food item for $T$. oreadicus. Moreover, during fieldwork one of the authors (CFDR) recorded an adult male climbing on a shrub of Cassia sp. and feeding on its flowers. Araújo (1987), studying T. oreadicus in Pará, found a reasonable proportion of plant material ( $18 \%$ by volume) in the diet, especially flowers of Ipomoea carajasensis Austin, 1981 (there is no available information about the specific volume of flowers). In another study, also in Pará, this species consumed mostly fruits $(25.3 \%$ by volume), with flowers consumed in low quantities ( $1.4 \%$ by volume) (Vitt, 1993). However, two other studies showed that this species consumed low volumes of plant material $(1.6 \%$ in Mato Grosso State and 3.2\% in Goiás State) (Colli et al., 1992; Faria and Araújo, 2004).

Rates of consumption of plant material between males and females were different $(61.7 \%$ for males and $33.0 \%$ for females). It has been demonstrated that for the congeneric $T$. torquatus the consumption of plant material increases with the increase of lizard size and that the larger adult males consumed a comparatively larger amount of plant material compared to adult females (Fialho et al., 2000). In several species that present an ontogenetic variation in plant consumption, with a greater consumption by larger individuals (Cooper and Vitt, 2002), the difference in consumption of plant material between sexes may be due to the larger body size of males in relation to that of females (Perez-Mellado and De La Riva, 1993; Vitt et al., 1996; Fialho et al., 2000).

The foot of $T$. oreadicus found in one female stomach was probably from an adult individual. The consumption of conspecifics has been observed in other Tropidurus species (e. g. T. montanus: Kiefer and Sazima, 2002; T. hygomi: Dias and Rocha, 2004; T. torquatus: Alvarez et al., 1985; Kiefer et al., 2006) and reinforces the opportunistic habits of these lizards, though predation is generally carried out by males (Rocha et al., 2000). Although we found only one foot in the diet of $T$. oreadicus we can consider that the adults of this species are a potential source of mortality to conspecific lizards.

Acknowledgments - This study is part of the results of the "Programa de Ecologia, Conservação e Manejo de Ecossistemas do Sudeste Brasileiro" and of the Southeastern Brazilian Vertebrate Ecology Project (Vertebrate Ecology Laboratory), both from the Departamento de Ecologia, Instituto de Biologia, Universidade do Estado do Rio de Janeiro. This study was supported by grants from CNPq (307653/03-0 and 477981/2003-8) to CFDR. CCS receives a graduate fellowship from FAPERJ. Cia Vale do Rio Doce provided logistic support in the area. A preliminary version of this manuscript was submitted to the "Anais do VI Simpósio de Ecossistemas Brasileiros". We then received notification from the Organizing Committee of the Symposium that the Annals would not be published due to lack of funding. We wish to thank Bianca M. Sales for her help in the diet analyses. Mara C. Kiefer and D. Vrcibradic kindly revised the text offering helpful suggestions.

\section{References}

ALVAREZ, BB., TORALES, G. and TEDESCO, ME., 1985. Comportamiento alimentario de uma poblacion de Tropidurus torquatus (Iguanidae) del Departamento Capital, Província de Corrientes, Argentina. Hist. Nat., vol. 5, no. 31, p. 281-288. 
ARAÚJO, AFB., 1987. Comportamento alimentar dos lagartos: o caso dos Tropidurus do grupo torquatus da Serra dos Carajás, Pará (Sauria: Iguanidae). An. Etol., vol. 5, p. 203-234.

BERGALLO, HG. and ROCHA, CFD., 1993. Activity patterns and body temperatures of two sympatric lizards with different foraging tactics in southeastern Brazil. Amphibia-Reptilia, vol. 14, no. 3, p. 312-315.

COLLI, GR., ARAÚJO, AFB., SILVEIRA, R. and ROMA, F., 1992. Niche partitioning and morphology of two syntopic Tropidurus (Sauria: Tropiduridae) in Mato Grosso, Brazil. J. Herpetol., vol. 26, no. 1 , p. 66-69.

COOPER JR., WE. and VITT, LJ., 2002. Distribution, extent, and evolution of plant consumption by lizards. J. Zool., vol. 257, p. 487-517.

CRUZ, FB., 1998. Natural history of Tropidurus spinulosus (Squamata: Tropiduridae) from the dry chaco of Salta, Argentina. Herpetol. J., vol. 8, no. 2, p. 107-110.

CRUZ, FB., SILVA, S. and SCROCCHI, GJ., 1998. Ecology of the lizard Tropidurus etheridgei (Squamata: Tropiduridae) from the dry chaco of Salta, Argentina. Herpetol. Nat. Hist., vol. 6, no. 1 , p. 23-31.

DIAS, EJR. and ROCHA, CFD., 2004. Tropidurus hygomi (NCN). Juvenile Predation. Herpetol. Rev., vol. 35, no. 4, p. 398-398.

DUNHAM, AE., 1983. Realized niche overlap, resource abundance, and intensity of interspecific competition. In HUEY, RB., PIANKA, ER. and SCHOENER, TW., Lizard Ecology, Studies of a Model Organism, Harvard University Press, Cambridge. p. 261-280

FARIA, RR. and ARAÚJO, AFB., 2004. Sintopy of two Tropidurus lizard species (Squamata: Tropiduridae) in a rocky Cerrado habitat in Central Brazil. Braz. J. Biol., vol. 64, no. 4, p. 775-786.

FIALHO, RF., ROCHA, CFD. and VRCIBRADIC. D., 2000. Feeding ecology of Tropidurus torquatus: ontogenetic shift in plant consumption and seasonal trends in diet. J. Herpetol., vol. 34, no. 2, p. 325-330.

FROST, DR., RODRIGUES, MT., GRANT, T. and TITUS, TA., 2001. Phylogenetics of the lizard genus Tropidurus (Squamata: Tropiduridae: Tropidurinae): direct optimization, descritive efficiency, and sensitivity analysis of congruence between molecular data and morphology. Mol. Phylog. Evol., vol. 21, no. 3 , p. $352-371$.

HUEY, RB., PIANKA, ER. and VITT, LJ., 2001. How often do lizards "run on empty"? Ecology., vol. 82, no. 1, p. 1-7.

JULIANO, RF., BASTOS, RP. and MOTTA, JAO., 2002. Tropidurus torquatus (Calango). Diet. Herpetol. Rev., vol. 33, no. 1 , p. 54-55.

KIEFER, MC. and SAZIMA, I., 2002. Tropidurus montanus (NCN). Cannibalism. Herpetol. Rev., vol. 33, no. 2, p. 36.

KIEFER, MC., VAN SLUYS, M. and ROCHA, CFD., 2005. Body temperatures of Tropidurus torquatus (Squamata, Tropiduridae) from coastal populations: Do body temperatures vary along their geographic range?. J. Therm. Biol., vol. 30, no. 6 , p. $449-456$.
KIEFER, MC., SIQUEIRA, CC., VAN SLUYS, M. and ROCHA, CFD., 2006. Tropidurus torquatus (Collared Lizard, Calango). Prey. Herpetol. Rev., vol. 37, no. 4, p. 475-476.

KOKUBUM, MC. and LEMOS, FG., 2004. Tropidurus torquatus (Calango). Saurophagy. Herpetol. Rev., vol. 35, no. 3 , p. $270-271$.

PEREZ-MELLADO, V. and DE LA RIVA, I., 1993. Sexual size dimorphism and ecology: the case of a tropical lizard, Tropidurus melanopleurus (Sauria: Tropiduridae). Copeia, vol. 1993, no. 4, p. 969-976.

PINTO, ACS., WIEDERHECKER, HC. and COLLI, GR., 2005. Sexual dimorphism in the Neotropical lizard, Tropidurus torquatus (Squamata, Tropiduridae). Amphibia-Reptilia, vol. 26, no. 2 , p. 127-137.

ROCHA, CFD and BERGALLO, HG., 1990. Thermal biology and flight distance of Tropidurus oreadicus (Sauria Iguanidae) in an area of Amazonian Brazil. Ethol. Ecol. Evol., vol. 2, no. 3, p. 263-268.

-, 1994. Tropidurus torquatus (Collared Lizard). Diet. Herpetol. Rev., vol. 25, no. 2, p. 69.

ROCHA, CFD., VRCIBRADIC, D. and ARAÚJO, AFB., 2000. Ecofisiologia de Répteis de Restinga Brasileiras, In ESTEVES, FA. and LACERDA, LD. Ecologia de restingas e lagoas costeiras, NUPEM/UFRJ, Rio de Janeiro. p. 117-149

ROCHA, CFD., DUTRA, GF., VRCIBRADIC, D. and MENEZES, VA., 2002. The terrestrial reptile fauna of the Abrolhos Archipelago: species list and ecological aspects. Braz. J. Biol., vol. 62, no. 2, p. 285-291.

RODRIGUES, MT., 1987. Sistemática, ecologia e zoogeografia dos Tropidurus do grupo torquatus ao sul do Rio Amazonas (Sauria, Iguanidae). Arq. Zoo., vol. 31, p. 105-203.

-, 1988. Distribution of lizards of the genus Tropidurus in Brazil (Sauria, Iguanidae), In VANZOLINI, PE. and HEYER, WR. Proceedings of a Workshop on Neotropical Distribution, Academia Brasileira de Ciências, Rio de Janeiro. p. 413-425.

SECCO, RS. and MESQUITA, AL., 1983. Notas sobre a vegetação de canga de Serra Norte. Bol. Mus. Para. Emilio Goeldi, Sér. Bot., vol. 59, p. 1-13.

VAN SLUYS, M., 1992. Aspectos da ecologia do lagarto Tropidurus itambere (Tropiduridae), em uma área do sudeste do Brasil. Rev. Bras. Biol., vol. 52, no. 1, p. 181-185.

-, 1993, Food habits of the lizard Tropidurus itambere (Tropiduridae) in Southeastern Brazil. J. Herpetol., vol. 27, no. 3 , p. 347-351.

VITT, LJ., 1991. An introduction to the ecology of Cerrado lizards. J. Herpetol., vol. 25, no. 1, p. 79-90.

-, 1993. Ecology of isolated open formation Tropidurus (Reptilia: Tropiduridae) in Amazonian lowland rain forest. Can. J. Zool., vol. 71, no. 12, p. 2370-2390.

VITT, LJ., ZANI, PA. and CALDWELL, JP., 1996. Behavioural ecology of Tropidurus hispidus on isolated rock outcrops in Amazonia. J. Trop. Ecol., vol. 12, no. 1, p. 81-101.

ZAR, JH., 1999. Biostatistical analysis. Upper Saddle River, Prentice-Hall. 
